\title{
Adult caddisflies (Trichoptera) attracted to artificial lights in the middle reaches of the Shinano River from 2005 to 2007
}

\author{
KIMIO HIRABAYASHI*, GORO KIMURA \& EISO INOUE \\ Division of Applied Biology, Faculty of Textile Science and Technology, Shinshu University, 3-15-1 Tokida, Ueda 386-8567, Japan \\ (*) Corresponding author. E-mail: kimio@shinshu-u.ac.jp
}

\begin{abstract}
The species composition and abundance of adult caddisflies attracted to the illuminated showcase of a vending machine set along the middle reaches of the Shinano River were investigated every Sunday night from April to November in 2005 to 2007. A total of 1,405 adult caddisflies was collected during the investigation periods. We identified a total of 13 species belonging to 11 genera of 8 families. The most abundant species was Psychomyia acutipennis (Ulmer 1908) each year. Psychomyia acutipennis adults were collected from mid-May to the beginning of October (the range of mean air temperature was 13.8 to $27.7^{\circ} \mathrm{C}$ ), with its seasonal abundance divided into several peaks, i.e., the end of May, the beginning of June, and the end of August to the beginning of September in both 2006 and 2007. On the other hand, in 2005 when there was no large-scale summer flood and there were no marked abundance peaks. The present study suggests that the mean air temperature and summer floods impacted the seasonal abundance of $P$. acutipennis adults.
\end{abstract}

Key words: air temperature, annual trend, flood, light trap, Psychomyia acutipennis, seasonal abundance

\section{Introduction}

Members of the order Trichoptera are widely distributed and are frequently one of the most abundant taxa of insects in freshwater (Wiggins \& Currie 2008). Since the work of Parlato (1929), the hairy wings of the caddisfly have been known as an inhalant allergen throughout the world. However, there have been few previous reports on the abundance and seasonal trend of adult caddisflies in freshwater Japanese habitats. Therefore, the present study is intended to describe the adult caddisfly fauna associated with air temperature and floods during the years from 2005 to 2007, with the aim of obtaining valuable information for the control of public health pests in the middle reaches of the Shinano River.

\section{Materials and methods}

Adult caddisflies were collected every Sunday night from April to November of 2005 to 2007, by attracting them to the illuminated showcase of a vending machine set along the middle reaches of the Shinano River. Information about the Shinano River, details of the study site and the vending machine, and identification of adult caddisflies were provided by Kimura et al. (2008). Daily mean air temperatures and daily mean water levels during our study period were obtained from the Japan 
Meteorological Agency (2005, 2006 and 2007) and the Ministry of Land, Infrastructure, Transport and Tourism (2005, 2006 and 2007), respectively.

\section{Results and discussion}

Figure 1a shows the daily mean water level in the middle reaches of the Shinano River from April to November of each investigation year. The maximum daily mean water level was $2.94 \mathrm{~m}$ (19 July 2006) followed by $2.48 \mathrm{~m}$ (7 September 2007), for an average of $-0.05 \pm 0.25 \mathrm{~m}$ each investigation year. Although no record exists of the advisory water level $(0.80 \mathrm{~m})$ in 2005,2 records were available for 2006 and 2007 (Figure 1a). The daily mean air temperature ranged from $1.3^{\circ} \mathrm{C}(23$ November 2007) to $28.7^{\circ} \mathrm{C}\left(15\right.$ August 2007), averaging $17.2 \pm 6.5^{\circ} \mathrm{C}$ each investigation year (Figure 1b). A total of 1,405 adult caddisflies were collected from 2005 to 2007 from the end of April to the beginning of November, although none were collected on days when the daily mean air temperature was lower than $13.8^{\circ} \mathrm{C}$. The abundance of adults reached a maximum on 24 June 2007 (103 ind. / $20 \mathrm{~min} ., 17.4^{\circ} \mathrm{C}$ ) followed by 9 September 2007 (98 ind. $/ 20 \mathrm{~min} ., 25.1^{\circ} \mathrm{C}$ ).

We identified a total of 13 adult species belonging to 11 genera of 8 families (Table 1). Potamyia chinensis (Ulmer 1915) was collected in 2006 and 2007, Padunia sp. and Apatania aberrans (Martynov 1933) in 2006, Glossosoma ussuricum (Martynov 1934) in 2007, and the remainder (nine species) from 2005 to 2007. The most abundant species was Psychomyia acutipennis (Ulmer 1908) (1,201 individuals, 85.5\%) each year. According to Kimura et al. (2009), P. acutipennis larvae were also collected in riffles in the middle reaches of the Shinano River, suggesting that the massive numbers of adults attracted to the light of the vending machine showcases emerged from the river. Psychomyia acutipennis adults were collected from mid-May to the beginning of October (the range of mean air temperature was 13.8 to $27.7^{\circ} \mathrm{C}$ ), with its seasonal abundance divided into several peaks,
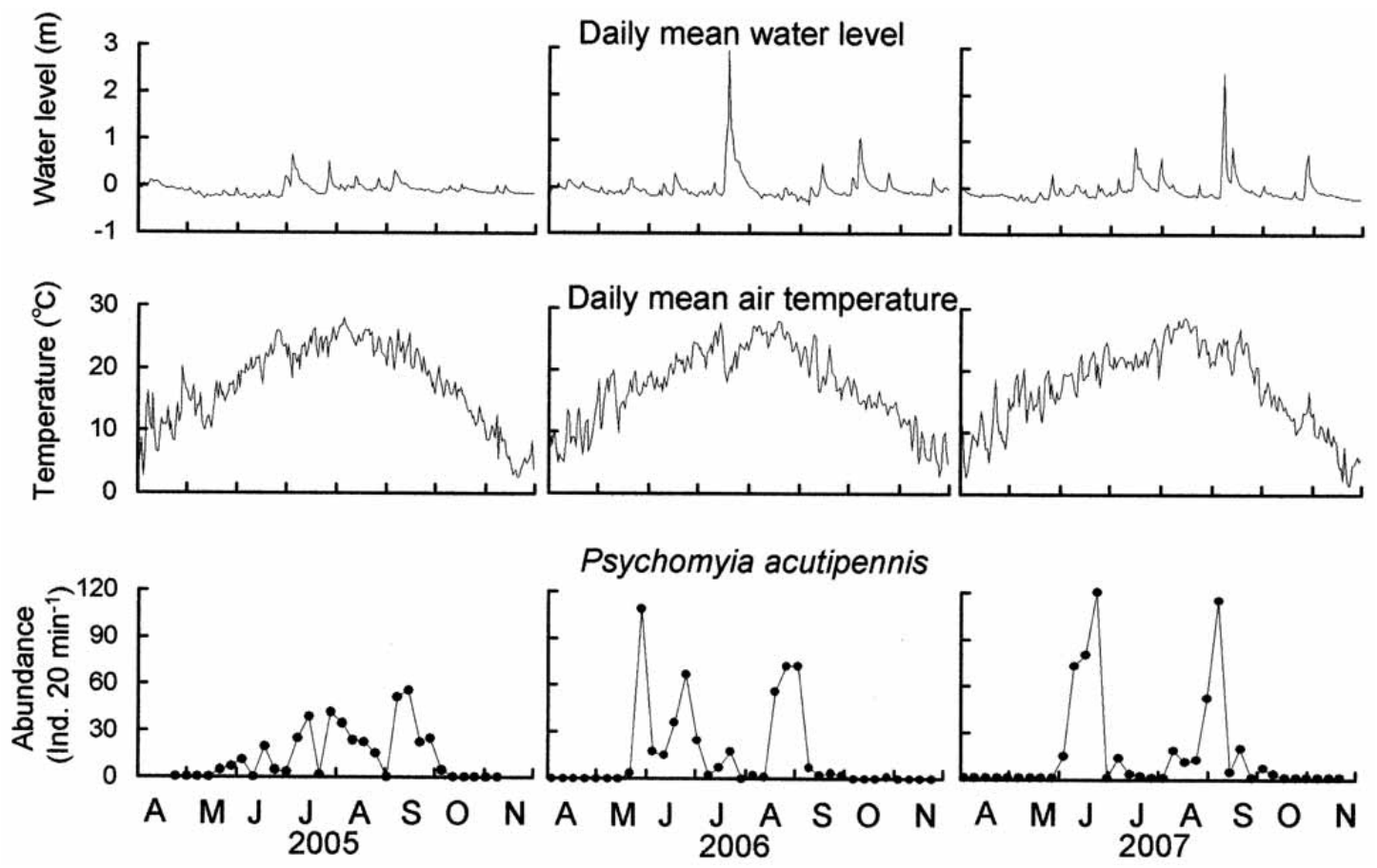

FIGURE 1. Seasonal changes, environmental conditions and abundance of Psychomyia acutipennis adults. Upper-a: comparative water level, Middle-b: mean air temperature (daily mean air temperature in 2006 according to Kimura et al. 2008), Lower-c: number of $P$. acutipennis adults caught per 20 minutes (data of 2006, modified after the paper by Kimura et al. 2008). 
i.e., the end of May, the beginning of June, and the end of August to the beginning of September in both 2006 and 2007 (Fig. 1c). On the other hand, in 2005 when there was no large-scale summer flood, there were no marked abundance peaks (Fig. 1a, c). In addition, no P. acutipennis adults were collected on days when the daily mean air temperature was lower than $13.8^{\circ} \mathrm{C}$ during the investigation periods.

According to Kimura et al. (2008), the daily mean air temperature revealed significant correlations with the abundance of adult $P$. acutipennis. The present study suggested that the mean air temperature and summer floods impacted the seasonal abundance of P. acutipennis adults. Kimura et al. (2008) reported that local residents along the Shinano River may have been exposed to periodic invasions of adult $P$. acutipennis, a finding that is in agreement with that of the present study.

TABLE 1. List of adult caddisflies in the middle reaches of the Shinano River (data of 2006, modified after the paper by Kimura et al. 2008).

\begin{tabular}{|c|c|c|c|c|c|c|c|c|}
\hline & \multicolumn{2}{|c|}{2005} & \multicolumn{2}{|c|}{2006} & \multicolumn{2}{|c|}{2007} & \multicolumn{2}{|c|}{ Total } \\
\hline & Ind. No. & $\%$ & Ind. No. & $\%$ & Ind. No. & $\%$ & Ind. No. & $\%$ \\
\hline \multicolumn{9}{|l|}{ Rhyacophilidae } \\
\hline Rhyacophila yamanakensis Iwata 1927 & 1 & 0.3 & 1 & 0.2 & 2 & 0.4 & 4 & 0.3 \\
\hline \multicolumn{9}{|l|}{ Hydroptilidae } \\
\hline Hydroptila phenianica Botosaneanu 1970 & 6 & 1.7 & 11 & 2.1 & 6 & 1.1 & 23 & 1.6 \\
\hline \multicolumn{9}{|l|}{ Glossosomatidae } \\
\hline Glossosoma ussuricum (Martynov 1934) & 0 & 0.0 & 0 & 0.0 & 1 & 0.2 & 1 & 0.1 \\
\hline Padunia sp. & 0 & 0.0 & 1 & 0.2 & 0 & 0.0 & 1 & 0.1 \\
\hline \multicolumn{9}{|l|}{ Stenopsychidae } \\
\hline Stenospyche marmorata Navás 1920 & 10 & 2.9 & 10 & 1.9 & 5 & 0.9 & 25 & 1.8 \\
\hline \multicolumn{9}{|l|}{ Psychomyiidae } \\
\hline Psychomyia acutipennis (Ulmer 1908) & 295 & 86.0 & 445 & 84.3 & 461 & 86.3 & 1201 & 85.5 \\
\hline \multicolumn{9}{|l|}{ Hydropsychidae } \\
\hline Cheumatopsyche brevilineata (Iwata 1927) & 3 & 0.9 & 2 & 0.4 & 5 & 0.9 & 10 & 0.7 \\
\hline C. infascia Martynov 1934 & 8 & 2.3 & 7 & 1.3 & 14 & 2.6 & 29 & 2.1 \\
\hline Hydropsyche orientalis Martynov 1934 & 9 & 2.6 & 32 & 6.1 & 30 & 5.6 & 71 & 5.1 \\
\hline H. selysi Ulmer 1907 & 9 & 2.6 & 11 & 2.1 & 5 & 0.9 & 25 & 1.8 \\
\hline Potamyia chinensis (Ulmer 1915) & 0 & 0.0 & 4 & 0.8 & 2 & 0.4 & 6 & 0.4 \\
\hline \multicolumn{9}{|l|}{ Apataniidae } \\
\hline Apatania aberrans (Martynov 1933) & 0 & 0.0 & 1 & 0.2 & 0 & 0.0 & 1 & 0.1 \\
\hline \multicolumn{9}{|l|}{ Goeridae } \\
\hline Goera japonica Banks 1906 & 2 & 0.6 & 3 & 0.6 & 3 & 0.6 & 8 & 0.6 \\
\hline Total & 343 & 100.0 & 528 & 100.0 & 534 & 100.0 & 1405 & 100.0 \\
\hline
\end{tabular}

\section{Acknowledgements}

We are very grateful to Tezuka Manufacturing Co., Ltd., personnel for allowing us to collect samples from their works. Part of the present study was supported by the River Ecology Research Group of Japan (Chikuma River Research Group) and the Foundation of River \& Watershed Environment Management. This paper is dedicated to the first principal, Chotaro Harizuka, on the occasion of $100^{\text {th }}$ anniversary of Faculty of Textile Science and Technology, Shinshu University.

\section{References}

Japan Meteorological Agency. (2005, 2006, 2007) Weather, Climate \& Earthquake Information. Available from http://www.jma.go.jp (accessed 15 October 2009) (In Japanese).

Kimura, G., Inoue, E. \& Hirabayashi, K. (2008) Seasonal abundance of adult caddisfly (Trichoptera) in the middle 
reaches of the Shinano River in Central Japan. In: Robinson, W.H. \& Bajomi, D. (Eds.), Proceedings of the 6th International Conference on Urban Pests, Országos Oktatási Központ-Press Kft., Veszprem, pp. 259-266.

Kimura, G., Inoue, E. \& Hirabayashi, K. (2009) Changes in the species composition and density of caddisflies (Trichoptera) after an excavation work in the middle reaches of the Shinano River, Japan. Japanese Journal of Environmental Entomology and Zoology, 20, 17-26.

Ministry of Land, Infrastructure and Transport, Japan (2005, 2006, 2007). Water Information Systems. Available from http://www 1.river.go.jp (accessed 15 October 2009) (In Japanese).

Parlato, S.J. (1929) The case of coryza asthma due to sand-flies (caddis flies). Journal of Allergy, 1, 35-42.

Wiggins, G.B. \& Currie, D.C. (2008) Trichoptera Families. In: Merritt, R.W., Cummins, K.W. \& Berg, M.B. (Eds.), An Introduction to the Aquatic Insects of North America. Fourth Edition, Kendall/Hunt, Iowa, pp. 439-480. 